\title{
Analyzing Trend of Tropical Cyclone Activity Along Odisha Coast, India
}

\author{
Manoranjan Mishra \\ Khallikote University \\ Namita Pattnaik \\ Gangadhar Meher University \\ Manoj Kumar Dash \\ Khallikote University \\ Dambaru Ballab Kattel \\ University of the Chinese Academy of Sciences \\ Shailendra Kumar Mishra ( $\sim$ shailendra17@gmail.com ) \\ University of Allahabad https://orcid.org/0000-0002-1840-0374
}

\section{Research}

Keywords: Tropical cyclone, severe cyclonic storms, economic damage and Odisha coast

Posted Date: June 1st, 2020

DOI: https://doi.org/10.21203/rs.3.rs-30112/v1

License: (c) (1) This work is licensed under a Creative Commons Attribution 4.0 International License. Read Full License 


\section{Abstract}

A general perception among scientific community and policy makers of developing countries exists that intensity and frequency of tropical cyclones are increasing over time due to climate change and global warming. In the present study, we have tried to investigate the trend and variability of tropical cyclone landfall along the Odisha coast, India. The data pertaining to landfall of the tropical cyclones were collected from Indian Metrological Department and were further filtered using Gaussian filter. The results were plotted in graphical form. Correlation and linear regressions analyses were carried out. The results highlight that the frequency and intensity of tropical cyclone exhibit a decreasing trend. It can be thus be inferred that growing economic loss and loss of lives are due to growing exposure of unplanned population settlements and business investments to extreme events. Therefore socio-economic landscapes need to be adjusted to the landfall of cyclone than blaming natural forces for the loss of lives and properties. Findings of the present study may help policy makers devising future policies in coastal zones.

\section{Introduction}

The tropical cyclones are one of the most damaging and powerful forces induced by the earth system during the last century. ${ }^{1-4}$ The vulnerability due to tropical cyclone is rising around the world owing to increase in human habitats and critical infrastructure along the coastlines. It is difficult to establish parametric relationship between global warming and variability of tropical cyclone all over the world. ${ }^{5-12}$ Kossini, 2018, finds that translation speed of tropical cyclones has decreased by ten percent during year1949 to 2016 around the world which is well correlated with the changes in atmospheric conditions induced by anthropogenic warming. ${ }^{13}$ But, there is an observed trend that tropical cyclones over Bay of Bengal have intensified in their sustained wind speed and cyclone size. ${ }^{14}$ The severe cyclone Fani which made a landfall at Odisha coast on May 3, 2019 causing rampant economic damage is unique in nature due to its timing, strength and trajectory. Comparatively warmer Bay of Bengal provides conducive environmental condition for intensification of such cyclonic storms. ${ }^{15}$ Further, scientific evidence also exists about drastic increase in power dissipation index (PDI) during last two decades. ${ }^{16-18}$ There is a scientific perception that tropical cyclone in the 21 st century are becoming more destructive in nature. It is generally attributed to the increase in frequency and intensity of cyclone induced by rising ocean temperature and other climatic perturbations. Rising temperature of the earth systems i.e. roughly 0.8 degree Celsius warmer than the last century is supposedly directly linked with the timing, frequency and intensity of tropical cyclones.

The increased destructive potential of tropical cyclone along Odisha coast is a serious concern because the population density and economic investments are increasing at a rapid rate in these areas. The cyclonic activity over Bay of Bengal (BoB) has frequency five times more than Arabian Sea. ${ }^{19}$ According to Singh et al. (2000), both frequency and intensity of tropical cyclonic activities have increased in the 
BoB during last 122 years (1877-1998). ${ }^{20}$ Thus, the States bordering Bay of Bengal are more vulnerable to tropical cyclones compared to Arabian Sea.

On the contrary, some studies over the North Indian Ocean show that there exists no long term trend of increasing frequency and intensity of tropical cyclone yet some crucial points of contention remains about the veracity of decadal variations. ${ }^{21-23}$ Again, no significant relations are found between tropical cyclonic activity in North Indian Ocean and El Niño-Southern Oscillation (ENSO). ${ }^{22,24}$ However, two important questions remain unanswered about frequency of tropical cyclone land falling at the Odisha coast. First, structure and significance of annual, decadal and other preferred variability of land falling of cyclones are poorly understood in the study area. Second, economic damage and destruction increased in past quarter century along Odisha coast has a negative correlation with any actual increase in frequency or intensity of cyclones.

Therefore, an investigation regarding variability of the landfall frequency of tropical cyclones will provide insight about trends in past and important understanding on the continental impact of these cyclonic activities. The present study evaluates inter annual and decadal variability of tropical cyclone activity along Odisha coast, and further examines the modulation of total seasonal cyclonic activity with trend analysis in North Indian Ocean during the last century.

\section{Materials And Methods}

\section{Study area}

The coastal zone of Odisha is extended over $480 \mathrm{~km}$ from the district Balasore in north to Ganjam in the south having a co-ordinate of $17^{\circ} 48^{\prime} \mathrm{N}, 81^{\circ} 24^{\prime} \mathrm{E}$ to $22^{\circ} 34^{\prime} \mathrm{N}, 87^{\circ} 29^{\prime} \mathrm{E}$ (Fig. 1). This part constitutes $16 \%$ of geographical area of the state and is inhabited by $33 \%$ of the total population. ${ }^{25}$ The coastal landscape of Odisha is $5033.64 \mathrm{sq} \mathrm{km}$ and is divided into five homogenous geomorphical units using geospatial technology. The response of shore line to severe cyclonic storms is cyclic in nature including phase of erosion, phase accretion and phase of stabilization. ${ }^{26,27}$ Apart from storms, sea level rise will induce damage and economic loss in costal Odisha in coming days. ${ }^{28}$ It also has one of the world heritage sites namely Sun temple in Konarak, attracting large number of tourists and pilgrimages over the year.

Nevertheless, this region also had experienced 128 cyclonic storms between years 1804 to 2000 , and also remained one of the most vulnerable regions for climate induced natural disasters in Indian subcontinent. Consequently, it had undergone considerable damage of life and property in recent past. ${ }^{29,}{ }^{30} \mathrm{Again}$, it has been estimated that Odisha coast had witnessed $37 \%$ of total cyclonic storms landfall in the eastern coastline of India during last 109 years. In another calculation, climatologically it is expected to witness maximum cyclonic storm between year 1981 to $2030 .{ }^{31}$

(Source: Indian Metrological Department e-atlas (http://www.rmcchennaieatlas.tn.nic.in))

\section{Data type}


The data pertaining to landfall of tropical cyclone is used for analyses in the present study. Data obtained from cyclonic e-atlas of Indian Meteorological Department includes frequency of tropical cyclones land fall, position observed hitting the mainland of coastal Odisha and central maximum wind speed. Further, the central maximum wind speed is classified into three classes - (a) depression ( $D$, with maximum central wind speed less than $34 \mathrm{kn}$ or $17 \mathrm{~m} / \mathrm{s}$ ), (b) cyclonic storm (CS, 34- 64kn, 17-32.6 m/s) and (c) severe cyclonic storms (SCS, more than $64 \mathrm{kn}, 32 \mathrm{~m} / \mathrm{s}$ ). The data spans from 1891 to 2012 are interpolated for adjacent area of the study having co-ordinate of $17^{\circ} 48^{\prime} \mathrm{N}, 81^{\circ} 24^{\prime} \mathrm{E}$ to $22^{\circ} 34^{\prime} \mathrm{N}, 87^{\circ} 29^{\prime} \mathrm{E}$. The time series of frequency of landfall of tropical cyclones (depression, cyclonic storms and severe cyclonic storms) are filtered with Gaussian filter and the outputs were plotted in graphs for visual interpretation and preliminary analysis. ${ }^{32}$ In this study, frequency of depression, cyclonic storms and severe cyclonic storm were pooled for each decade to understand inter-decadal variation.

\section{Analyses}

To understand the relationship among depression, cyclonic storm and severe cyclonic storms (i.e. tropical cyclones) correlation has been carried out. Further, separate linear regression models were conducted considering depression, cyclonic storm and severe cyclonic storm as dependent variables, to evaluate the effect of time (decadal variation) and other tropical cyclones apart from the one considered as dependent variable in the model.

\section{Results}

A total of 1301 tropical cyclonic storms were generated over Bay of Bengal during the past 121 years (1891-2011). Among those 33\% (389) had their landfall on Odisha coast. Out of these tropical cyclonic storms, $73 \%$ were tropical depression, $20 \%$ were cyclonic storms and $7 \%$ were severe cyclonic storms. Noticeable annual fluctuation is observed in the number of landfall of tropical cyclones along Odisha coast with the maximum of 8 in years 1990, 1927 and 1934, and a minimum of 0 in years 1901, 1987, $1993,1996,1998,2000$ and 2002. There had been more number of landfall of tropical cyclones during the early 1900s and after 1930, while seldom around 1980 and 2011 (Figure - 2). Over the decades, frequency of tropical depression has increased and the frequency of cyclonic storm has decreased however no clear trend has been observed for sever cyclonic storms. However, prominently marked decreases are found in last four decades (Figure-3).

The months of June (52), July (97), August (119) and September (85) are high probability months accounts for $91 \%$ of the reported cyclones landfall at Odisha coast between the year 1891-2011 (Figure4). The cyclonic storm season starts in the month of May/June, increases with July, peaks in August and decreases to low frequency in the month of November/December. This pattern corresponds with the time of the year when convective heating is at its highest in the province, therefore high storm frequencies are anticipated. Although $50 \%$ of sever cyclonic storms occurred in the month of October but depression and cyclonic storms have equivalent pattern to total land falling of tropical cyclonic storms in Odisha. It is 
evident from Figure-4 that a number of severe cyclonic storms occur during peak summer months but the threat of storms is not substantially reduced until November.

Table- I shows a negative correlation between decadal frequency of tropical depression and cyclonic storm. No significant correlation has been observed between decadal frequency of depression and decadal frequency of sever cyclonic storm. Similarly, relationship between decadal frequency of cyclonic storm and sever cyclonic storm is also found to be non significant.

\section{Table-I}

Correlation coefficient showing relationship among various types of tropical storms

\begin{tabular}{|llll|}
\hline & $\begin{array}{l}\text { Frequency of } \\
\text { depression }\end{array}$ & $\begin{array}{l}\text { Frequency of } \\
\text { cyclonic storm }\end{array}$ & $\begin{array}{l}\text { Frequency of sever } \\
\text { cyclonic storm }\end{array}$ \\
\hline Frequency of depression & - & $-0.87^{\star *}$ & 0.33 \\
\hline $\begin{array}{l}\text { Frequency of cyclonic } \\
\text { storm }\end{array}$ & - & 0.18 \\
\hline $\begin{array}{l}\text { Frequency of sever } \\
\text { cyclonic storm }\end{array}$ & & - \\
\hline
\end{tabular}

Results of the multiple regression analysis illustrate that decadal frequency of cyclonic storm and time are the two significant predictors of the frequency of depression. Frequency of depression is positively associated with the time however frequency of cyclonic storm is negatively associated. Time remains a significant predictor of all kinds of tropical storms yet decadal frequency of depression is also found to be significant predictor of cyclonic and sever cyclonic storms.

\section{Table-ll}

Results of multiple regression considering time and the kinds of tropical cyclones, apart from the one considered as dependent variable, as predictors. 


\begin{tabular}{|llllll|}
\hline Dependent variable & Significant predictor $(\mathbf{s})$ & $\boldsymbol{\beta}$ & $\mathbf{S E}$ & $\begin{array}{l}\mathbf{p}- \\
\text { value }\end{array}$ & $\mathbf{R}^{2}$ \\
\hline Decadal frequency of depression & $\begin{array}{l}\text { Decadal frequency of cyclonic } \\
\text { storm }\end{array}$ & -1.49 & 0.56 & 0.01 & 0.79 \\
& Time & 0.65 & 0.86 & 0.02 & \\
\hline $\begin{array}{l}\text { Decadal frequency of cyclonic } \\
\text { storm }\end{array}$ & $\begin{array}{l}\text { Decadal frequency of } \\
\text { depression }\end{array}$ & -0.32 & 0.11 & 0.02 & 0.96 \\
& Time & -0.72 & 0.37 & 0.01 & \\
\hline $\begin{array}{l}\text { Decadal frequency of sever } \\
\text { cyclonic storm }\end{array}$ & $\begin{array}{l}\text { Decadal frequency of } \\
\text { depression }\end{array}$ & -1.41 & 0.11 & 0.01 & 0.84 \\
& Time & -1.38 & 0.37 & 0.01 & \\
\hline
\end{tabular}

(Source

Indian Meteorological Department, New Delhi)

It is abundantly clear from Figure - 5 that except in year 1999, loss of human lives has substantially reduced during lost few decades. On the contrary, loss of properties has exponentially increased during this period which generally attributed to fury of natural forces.

\section{Discussion}

Finding of the present study reveals that landfall frequencies of tropical cyclones along Odisha coast have exhibited a decreasing trend in long term analysis at different rates. A study by Sahoo and Bhaskaran (2018) reported that the Odisha have been hit with 46 cyclones in the last four decades. ${ }^{18}$ Again, they have highlighted that combined frequencies of pre and post-monsoon cyclone frequencies in Odisha are the highest as compared to other States of east coast of India. Another notable observation of our study is that the tracks of pre-monsoon cyclone are shorter in length as compared to post-monsoon cyclone. It can thus be inferred that longer duration inside the sea produces cyclones with higher intensity during post monsoon compared to pre-monsoon season. But, super cyclone Fani produced in month of April and May 2019 is an exception. It developed around equator and moved upward for 7 days before landfall, gaining moisture and momentum from shallow sea, and thus generated stronger winds.

The trend analysis highlights that intensity and frequency of cyclones are decreasing during last 100 years but natural forces were squarely blamed after each and every severe tropical cyclone landfall along the maritime States. On contrary, it has been stated by Peduzzi (2012) that frequency and intensity of landfall of tropical cyclones is stable across the globe during last 40 years. Yet the global population has increased $86 \%$ between the years 1970 to 2010 and so is the exposure to the risk of tropical cyclones has increased globally. ${ }^{1,33}$ 
Further, Sahoo and Bhaskaran (2018) observed that energy metrics such as in power dissipation index (PDI) and accumulated cyclone energy (ACE) directly linked with the maximum sustained wind speed of a cyclonic system during last 30 years along Odisha coast is increasing the exposure of risk to the coastal communities. ${ }^{18}$ On the contrary, some of the studies have shown increasing trend of intensification of cyclones in the month of November and May in Northern Indian Ocean (Singh et al., 2000). ${ }^{34}$ Unfortunately, Paradeep port located in east coast of India was affected by sever cyclonic storms for four times during post monsoon season. ${ }^{35}$ There is a positive correlation between the total number of tropical cyclones generated in Bay of Bengal and the proportion of landfall of tropical cyclones along Odisha coast, with a correlation coefficient of .092. This coefficient rises to 0.47 (significant at 0.01 level), if some years are omitted from the analysis. The analysis above highlight that intensity and frequency of cyclone are decreasing in last centuries but economic damage is increasing. This increased vulnerability for loss of properties due to tropical cyclones may be on account of greater wealth accumulation along the coastline owing to rapid economic growth, speedy infrastructural development and consequent enhanced exposure to greater percentage of population inhabiting along the coast in last 50 years. The need of hour is to provide accurate comprehensive information of track of cyclones, maximum sustained wind speed and central pressure drop to map the vulnerability of a given location.

\section{Conclusion}

There is a common perception in the media, coastal resources managers and policy makers that frequency and intensity of tropical cyclones along Odisha coast have caused more damage over the years. Indirectly, natural forces were squarely blamed after each and every severe tropical cyclone landfall along the maritime state. However, if natural forces alone were to be blamed, then severe tropical cyclone Phailin, 2013 and Fani, 2019 would have had an equal impact. It would have invariably affected the most vulnerable sections of the society, who commonly owe their condition to human policies and practices. Furthermore, the overall composition, timing, strength, trajectory and consequence of landfall of tropical cyclones along Odisha coastline are poorly understood before. ${ }^{36}$ Contrary to common perception, this study highlights that frequency and intensity of tropical activity has a decreasing trend in last century. We are now in Age of Human being called Anthropocene and considering severe cyclonic storms like Fani, Phailin and Super Cyclone 1999 are act of nature, is a contradiction. The intensification of cyclonic storms and economic damages are human induced but not the act of nature's fury. Thus the rampage caused by severe cyclonic storms is more due to societal factors than the metrological factors. The cyclone like Fani has exposed development failures in major cities such as Bhubaneshwar, Cuttack and Puri and call for developing a vigilant disaster management system, land-use planning, sustainable development of coastal districts, and insurance measures. It can be inferred that more integrated and holistic disaster risk reduction is the need of hour for managing all sphere of vulnerability in coming days. The governments of coastal States have to move from zero casualties to zero economic damage. The finding of this study can help coastal mangers, policy makers and decision makers and researchers for future investigation of ground realities of survival in cyclone belt. 


\section{Declarations}

Acknowledgements: Authors acknowledge Khallikote University for providing logistic support.

Author's contribution: All the authors have contributed substantially in data analyses and writing of the manuscript. All the authors have read and approved the final draft.

\section{Funding:}

No funding was received for this work.

\section{Availability of data and materials:}

Not applicable

\section{Competing interests:}

The authors declare that there are no competing interests.

\section{References}

1. Peduzzi, P., B. Chatenoux, H. Dao, A. D. Bono, C. Herold, J. Kossin, F. Mouton, and O. Nordbeck. 2012. Global trends in tropical cyclone risk. Nat Clim Change 2: 289-294.

2. Gupta, S., I. Jain, P. Johari, and M. Lal. Impact of Climate Change on Tropical Cyclones Frequency and Intensity on Indian Coasts. In Springer Series in Geomechanics and Geoengineering. 2018. (pp. 359-365). Springer International Publishing. https://doi.org/10.1007/978-3-319-77276-9_32.

3. Pruitt, J. N., A. G. Little, S. J. Majumdar, T. W. Schoener, and D. N. Fisher. 2019. Call-to-Action: A Global Consortium for Tropical Cyclone Ecology. Trends Ecol Evol 34 (7): 588-590. https://doi.org/10.1016/j.tree.2019.04.009.

4. $10.1007 / \mathrm{s} 12040-019-1227-1$

Rao, D. V. B., D. Srinivas, and G. C. Satyanarayana. 2019. Trends in the genesis and landfall locations of tropical cyclones over the Bay of Bengal in the current global warming era. Journal of Earth System Science 2019; 128(7). https://doi.org/10.1007/s12040-019-1227-1.

5. De, U. S., and K. S. Joshi. 1999. Interannual and interdecadal variability of tropical cyclones over the Indian seas. Deccan Geog 37: 5-21.

6. IPCC (Intergovernmental Panel on Climate Change)

IPCC (Intergovernmental Panel on Climate Change). 2001. Climate Change 2001: The Scientific Basis, Contribution of Working Group I to the Third Assessment Report of the IPCC. Houghton, J. T., et al., Cambridge University Press, 944 pp. Accessed from Cambridge University Press, The Edinburgh Building, Shaftesbury Road, Cambridge CB2 2RU England. Accessed on 23rd March 2017. 
7. Shepherd, J. M., and T. Knutson. 2007. The current debate on the linkage between global warming and hurricanes. Geogr Compass 1: 1-24.

8. Johnny, C. L. C., L. Kin-Sik, X. Ming, and Y. Qiuzhen. 2011. Variations of frequency of landfalling typhoons in East China. Int J Climato/32: 1450-1949.

9. IPCC (Intergovernmental Panel on Climate Change)

Managing the risks of extreme events and disasters to advance climate change adaptation Accessed on 12th March 2016

IPCC (Intergovernmental Panel on Climate Change). 2012. Managing the risks of extreme events and disasters to advance climate change adaptation. http://ipcc-wg2.gov/SREX/, p 582. Accessed on 12th March 2016.

10. Moon, I., S. Kim, and J. C. L. Chan. 2019. Climate change and tropical cyclone trend. Nature 570: E3E5. https://doi.org/10.1038/s41586-019-1222-3.

11. Kang, N., D. Kim, and J. B. Elsner. 2019. The contribution of super typhoons to tropical cyclone activity in response to ENSO. Sci Rep 9: 5046. https://doi.org/10.1038/s41598-019-41561-y.

12. Comparison of Reanalysis Data Sets to Comprehend the Evolution of Tropical Cyclones Over North Indian Ocean https://doi.org/10.1029/2019ea000978

Malakar, P., A. P. Kesarkar, J. N. Bhate, V. Singh, and A. Deshamukhya. Comparison of Reanalysis Data Sets to Comprehend the Evolution of Tropical Cyclones Over North Indian Ocean. Earth Space Sci 2020: 7(2). https://doi.org/10.1029/2019ea000978.

13. Kossini, J. P. A global slowdown of tropical-cyclone translation speed. Nature 2018; 558: 104-107; Author Correction Nature 2018; 564: E11-E16.

14. Singh, K., J. Panda, and M. Mohapatra. Robustness of best track data and associated cyclone activity over the North Indian Ocean region during and prior to satellite era. Earth Syst Sci 2020: 129(1). https://doi.org/10.1007/s12040-020-1344-x.

15. Bhardwaj, P., and O. Singh. 2019. Climatological characteristics of Bay of Bengal tropical cyclones: 1972-2017. Theor App/ Climatol 139 (1-2): 615-629. https://doi.org/10.1007/s00704-019-02989-4.

16. Emanuel, K. 2005. Increasing destructiveness of tropical cyclones over the past 30 years. Nature 436 : 686-688.

17. Murty, P. L. N., P. K. Bhaskaran, and R. Gayathri, et al. 2016. Numerical study of coastal hydrodynamics using a coupled model for Hudhud cyclone in the Bay of Bengal. Estuar Coast Shelf Sci 183: 13e27. https://doi.org/10.1016/j.ecss.2016.10.013.

18. Sahoo, B., and P. K. Bhaskaran. 2018. Multi-hazard risk assessment of coastal vulnerability from tropical cyclones e A GIS based approach for the Odisha coast. J Environ Manag 206: 1166-1178.

19. Sahoo, B., and P. K. Bhaskaran. 2015. Synthesis of tropical cyclone tracks in a risk evaluation perspective for the east coast of India. Aquat Procedia 4: 389e396. https://doi.org/10.1016/j.aqpro.2015.02.052. 
20. Singh, O. P., T. M. Ali Khan, and M. S. Rahman. 2000. Changes in the frequency of tropical cyclones over the North Indian Ocean. Meteorol Atmos Phys 75: 11-20.

21. Joseph, P. V., and P. K. Xavier. Monsoon rainfall and frequencies of monsoon depressions and tropical cyclones of recent 100 years and an outlook for the first decades of the 21 st century. Proc. TROPMET-99, Chennai, India, Indian Meteorological Society, 1999: 364-371. Accessed from Indian Meteorological Society, Chennai Chapter, Regional Meteorological Centre, 50 College Road, Chennai 600006, India.

22. Singh, O. P., and T. M. A. Khan. 1999. Changes in the frequencies of cyclonic storms and depressions over the Bay of Bengal and the Arabian Sea. SMRC Rep 1999; 2: 121 pp. Accessed from South Asian Association for Regional Co-operation, Meteorological Research Centre, Agargaon, Dhaka 1207, Bangladesh.

23. Srivastava, A. K., K. C. S. Ray, and De. 2000. US Trends in the frequency of cyclonic disturbances and their intensification over Indian seas. Mausam 51: 113-118.

24. Bhardwaj, P., D. R. Pattanaik, and O. Singh. 2019. Tropical cyclone activity over Bay of Bengal in relation to El Niño-Southern Oscillation. International Journal of Climatology 39 (14): 5452-5469.

25. Census. 2011. Census data online. Available at: http://www.censusindia.net/cendat/ Accessed on 5th March 2016.

26. Mishra, M. 2016. Geomorphic Regionalization of Coastal Zone Using Geospatial Technology. Int J Environ Geo-Inf 3 (2): 11-23.

27. Mishra, M., P. Chand, N. Pattnaik, D. B. Kattel, G. K. Panda, M. Mohanti, U. D. Baruah, S. K. Chandniha, S. Achary, and T. Mohanty. Response of long- to short-term changes of the Puri coastline of Odisha (India) to natural and anthropogenic factors: a remote sensing and statistical assessment. Environ Earth Sci 2019; 78(11). https://doi.org/10.1007/s12665-019-8336-7.

28. Mishra, M., N. Pattnaik, B. Padhi, and P. Mishra. 2016. Mental Model Mapping of Sea Level Changes: 125142 Analyzing the Public and Expert Perception of Bhitarkanika Marine Biosphere Reserve, Global Warming. In Sea Level Rise \& Community Adaptation Strategies, Siksha 'O' Anusandhan University, India, 125-145. Canada: Kwantlen Polytechnic University.

29. Dube, S. K., P. C. Sinha, A. D. Rao, and T. Murty. Storm Surge Prediction and Mitigation with Particular Reference to Orissa. In: Proceedings of the Workshop on Forecasting and Mitigation of Meteorological Disasters: Tropical Cyclones, Floods, and Droughts. Bhubaneswar: TROPMET 2002, pp. 62-87.

30. Mohanty, P. K., U. S. Panda, and P. Mishra. 2008. Monitoring and management of environmental changes along the Orissa coast. $J$ Coast Res 24 (2B): 13-27.

31. Mooley, D. A., and C. M. Mohile. 1983. A study of cyclonic storms incident on the different sections of the coast around the Bay of Bengal. Mausam 34: 139-152.

32. Hanna, E., and J. Cappelen. 2003. Recent cooling in coastal southern Greenland and relation with the North Atlantic Oscillation. Geophys Res Lett 39: 1-3. 
33. Peduzzi, P., H. Dao, and C. Herold, et al. 2009. Assessing global exposure and vulnerability towards natural hazards: the disaster risk index. Nat. Hazard. Earth Syst Sci 9: 1149-1159.

34. Singh, O. P., T. M. Alikhan, and M. S. Rahman. 2000. Changes in the frequency of tropical cyclones over the north Indian Ocean. Meteor Atmos Phys 75: 11-20.

35. Sridharan, S., and A. Muthuchami. 2002. Some salient features of the Bay of Bengal super cyclonic storm of October. Mausam 53: 237-241.

36. Kantamaneni, K., N. N. V. S. Rani, L. Rice, K. Sur, M. Thayaparan, U. Kulatunga, R. Rege, K. Yenneti, and L. C. Campos. 2019. A systematic review of coastal vulnerability assessment studies along Andhra Pradesh, India: Critical evaluation of data gathering, risk levels and migration strategies. Water11: 393. doi:10.3390/w11020393.

\section{Figures}

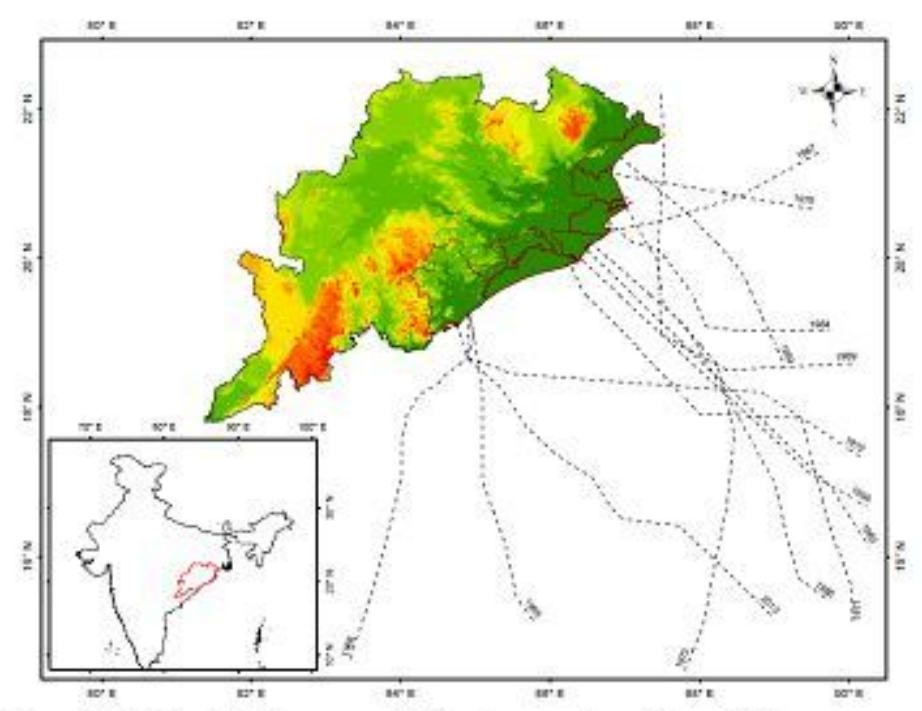

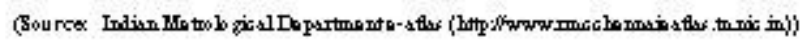

\section{Figure 1}

Location of study area and tracks of observed tropical storms along Odisha coast (1915 - 2018)

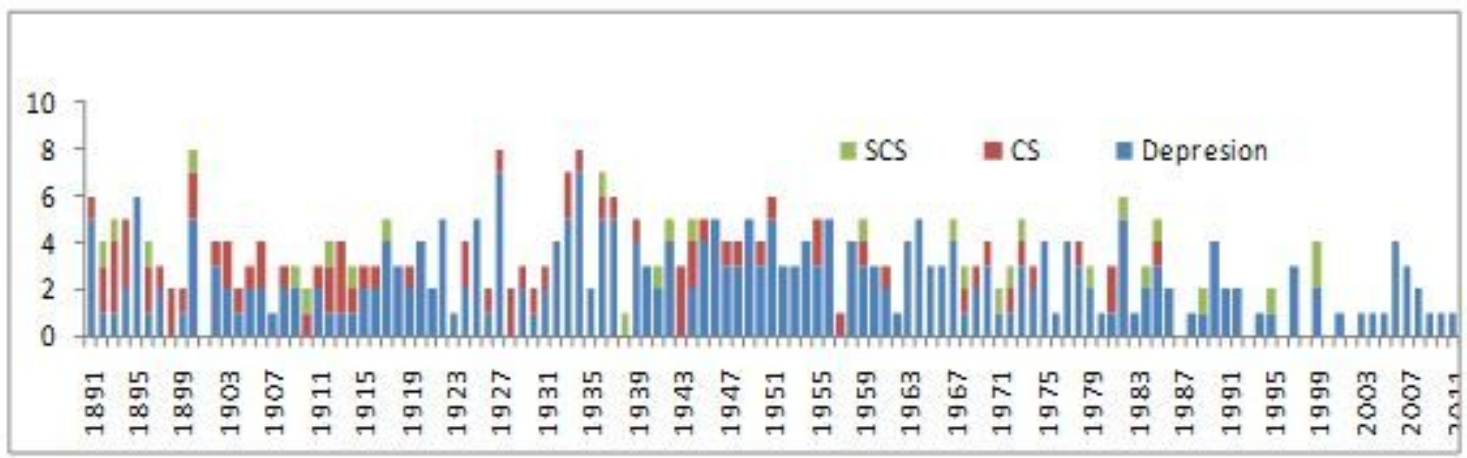

Figure 2 
Annual landfall of tropical cyclones along Odisha coast (1891-2011)

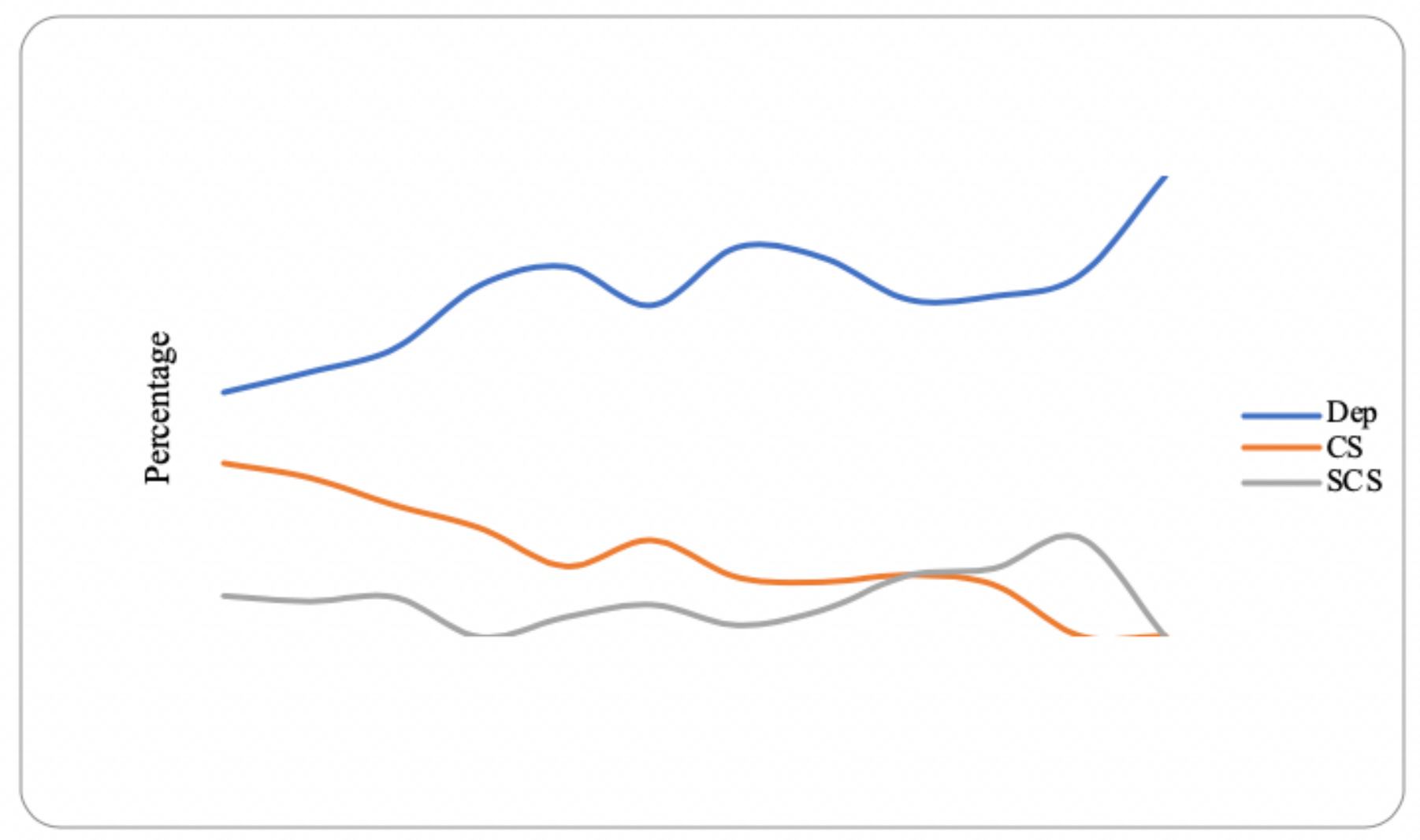

Figure 3

Decadal distribution of dipression, Cyclonic storms and sever cyclonic storms

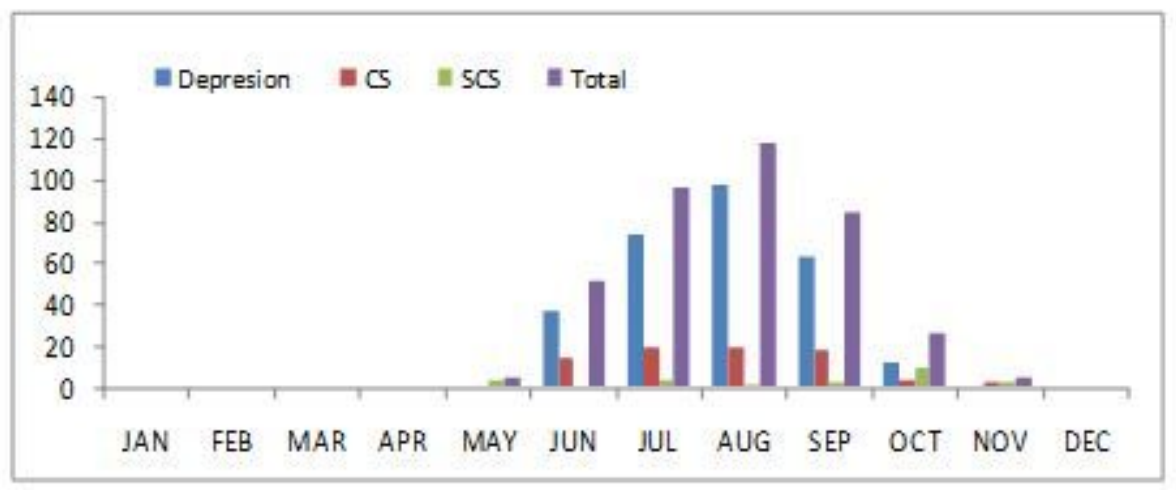

Figure 4

Month wise distribution of Tropical cyclones along Odisha coast (1891- 2011) 


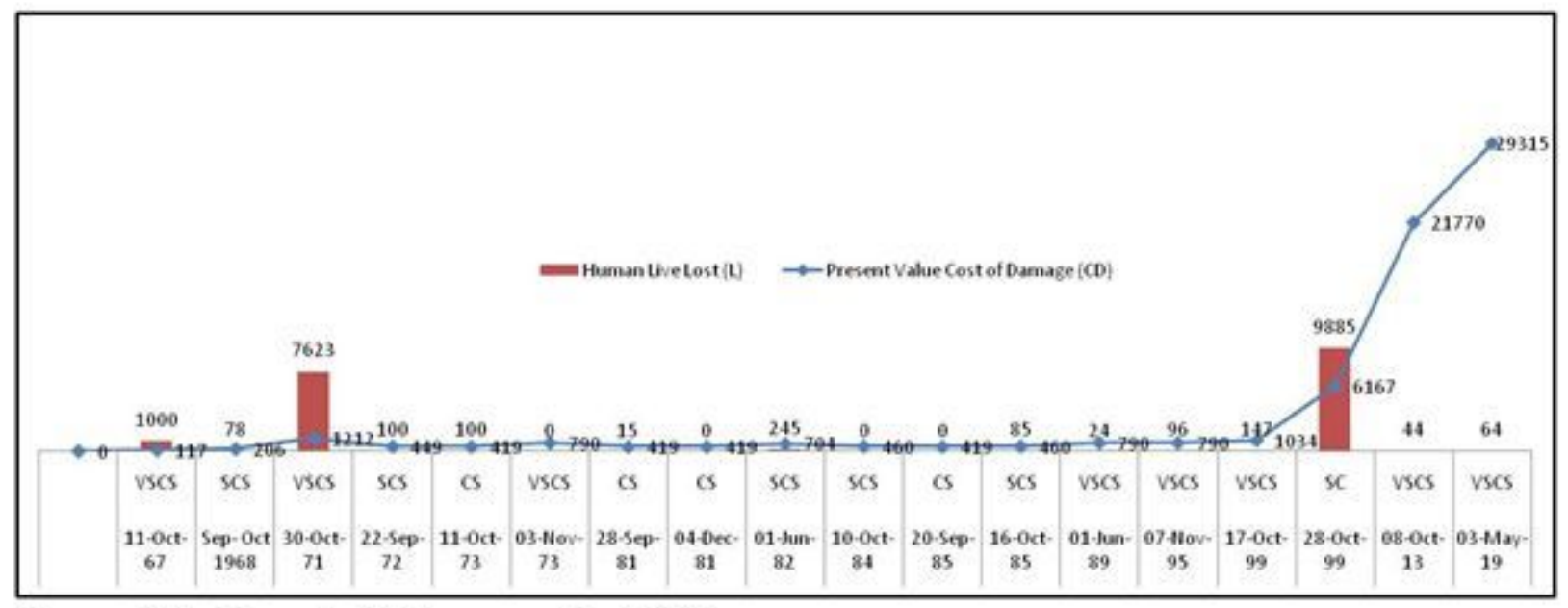

(Source: Indian Meteorological Department, New Delhi)

\section{Figure 5}

Loss of human lives (in numbers) and percent value cost of the properties (in crores) during last few decades. 